\title{
Cohesive Causes in Ancient Greek Philosophy and Medicine
}

\author{
Sean Coughlin
}

\begin{abstract}
This paper is about the history of a question in ancient Greek philosophy and medicine: what holds the parts of a whole together? The idea that there is a single cause responsible for cohesion is usually associated with the Stoics. They refer to it as the syn-

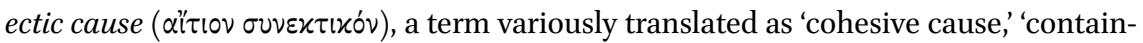
ing cause' or 'sustaining cause.' The Stoics, however, are neither the first nor the only thinkers to raise this question or to propose a single answer. Many earlier thinkers offer their own candidates for what actively binds parts together, with differing implications not only for why we are wholes rather than heaps, but also why our bodies inevitably become diseased and fall apart. This paper assembles, up to the time of the Stoics,

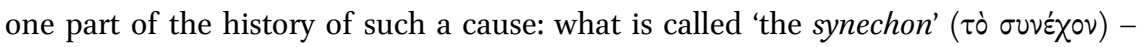
that which holds things together. Starting with our earliest evidence from Anaximenes ( sixth century вСЕ), the paper looks at different candidates and especially the models and metaphors for thinking about causes of cohesion which were proposed by different philosophers and doctors including Empedocles, early Greek doctors, Diogenes of Apollonia, Plato and Aristotle. My goal is to explore why these candidates and models were proposed and how later philosophical objections to them led to changes in how causes of cohesion were understood.
\end{abstract}

Parts and Wholes

Aristotle is often credited with the phrase, 'the whole is greater than the sum of its parts.' He may never have said it (it does not appear in any of the writings we have), but that has not stopped it from being quoted, almost always without a reference, in order to suggest an ancient pedigree for certain twentieth-century topics like holism, synergy, systems theory and emergence - topics at whose core is some kind of anti-reductive stance. ${ }^{1}$ This is not a coincidence. There

1 The attribution to Aristotle is remarkably common across disciplines. A sample: Vallero (2011) 8o on engineering and bioethics; Scalambrino (2018) 56-57 on psychology; Hanson

(C) SEAN COUGHLIN, 2021 | DOI:10.1163/9789004443143_012

This is an open access chapter distributed under the terms of the CC BY-NC-ND 4.o license $e_{\text {dingh }}$ in - 9789004443143 
is something Aristotelian about the phrase. After all, Aristotle is the ancient Greek philosopher most associated with the idea that some kinds of things in the world require explanations that go beyond the enumeration of their parts. If Aristotle asked you what a house is, you would not get away with telling him that it is the bricks and beams that went into building it, even if you managed to mention every one of them; and you certainly would not get away with telling him that bread is simply flour, salt, water and yeast. ${ }^{2}$ This is because, for Aristotle, if what we are talking about is not a heap of random things, but a whole, then citing only a list of ingredients misses something essential about the whole the ingredients are meant to explain. They fail to tell us how and why the parts are arranged the way they are and so why those parts form a unified thing. Not just any arrangement of materials, even of the appropriate materials, counts as a barn or a bagel, and Aristotle thinks the same goes for natural things as well. ${ }^{3}$ To understand what a horse is, it is not enough to give a list of every hair and hoof. Something more needs to be added, something about the overall form and arrangement of those parts for it to count as an explanation of a horse. People who study Aristotle today tend to refer to this as his hylomorphism: the idea that unified things, especially natural and living things, are composed of matter and form and that both need to be mentioned

(1995) 1 and Forrest (2018) 3 on systems theory; Hanson (2014) 84 on social theory; Elliott (2004) 454 on business; Marks et al. (2008) 599 on molecular biology. Schuster (2007) claims it is in Aristotle's Metaphysics, but does not cite a passage. It is also associated with Gestalt psychology, although no Gestalt theorist seems to have said it either, on which see Fuller (1990) 101-2. For a discussion of instances found on the internet (where it pops up quite often as well), see the blog, Sententiae Antiquae, 'No, Aristotle didn't write "a whole is greater than the sum of its parts."' Last accessed at sententiaeantiquae.com/2018/o7/06/no-aristotle-didnt -write-a-whole-is-greater-than-the-sum-of-its-parts/ on o2-o4-19.

2 The view is first stated in Plato's Phaedo (Pl. Phd.) 98b-e, but Plato develops it extensively in the Theaetetus, particularly the discussion of Hesiod's wheel at 206e-4-208b9. It is worth noting that this is not always the case. If someone asked me to explain the things on my desk, it would be fine to say that they are two books, a computer, a lamp; and it is perfectly fine (in North America anyway) to say that a quarter is twenty-five cents. These, according to Aristotle, are not wholes $(\tau \dot{\alpha} 0 \ddot{\lambda} \alpha)$, but totals $(\tau \dot{\alpha} \pi \dot{\alpha} \nu \tau \alpha)$. The total / whole distinction first shows up, as far as I know, also in Plato's Theaetetus (Pl. Tht.) at 204an-b1: 'Do you in fact call 'total' ( $\tau \dot{\partial} \pi \hat{\alpha} \nu$ ) and 'whole' ( $\tau \dot{o}$ ò $\lambda \circ v)$ the same thing or something else?' Aristotle takes up Plato's distinction in Metaphysics (Arist. Metaph.) 8.6, 1045a8-12, quoted below. On Theaetetus, see Harte (2002), especially chapter 1.

3 For the house example, see Aristotle, De partibus animalium (Arist. Part. an.) 1.1, 639b5-30. See also Aristotle, Topics 6.13, 15ob22-26. The extension of the analogy to natural objects is found in many works, but the point is made most explicitly at Aristotle, Meteorologica (Arist. Mete.) 4.12, 39ob2-14. 
in any explanation of what those things are. ${ }^{4}$ If, like Aristotle, we think the parts of a thing count as its matter, ${ }^{5}$ then it is not too far off to say he thinks 'the whole is more than the sum of its parts.' Some things are not identical to their parts alone: they are also their arrangement. As Aristotle would say, they are also their forms.

Now, while Aristotle never said, 'the whole is greater than the sum of the parts,' he does come close to saying it over a few pages in books 7 and 8 of his Metaphysics. At Metaphysics 8.6 he comes especially close. There he says that if something with parts is also a whole, then there must be some cause some reason - that explains why those parts form a whole in the first place. He writes:

What is the cause (ai $\tau_{10 v}$ ) of something being one? For, for everything that has a plurality of parts $\left(\pi \lambda \varepsilon^{i} \omega \mu \dot{\varepsilon} p \eta\right)$ and the totality ( $\left.\tau \dot{\partial} \pi \hat{\alpha} \nu\right)$ is not like a heap (oiov $\sigma \omega \rho o ́ s)$, but the whole ( $\tau \dot{0}$ ò $\lambda \circ v$ ) is something besides the parts $(\pi \alpha \rho \dot{\alpha} \tau \dot{\alpha} \mu o ́ p(\alpha)$, there is some cause, since even in the case of bodies, the cause of their being one is sometimes contact, other times sticki-

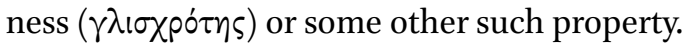

ARistotle, Metaphysics $8.6,1045^{a} 8-12^{6}$

One thing worth pointing out about this passage is that Aristotle does not say that the whole is greater ( $\mu \varepsilon \hat{\zeta}(\mathrm{ov}$ ) than the sum of its parts; rather, he says that there are cases (presumably self-evident ones) where the whole is something besides $(\pi \alpha \rho \alpha)$ or in addition to the parts. The difference between 'greater' and 'besides' is not merely grammatical. Aristotle, like some early Gestalt theorists, thinks the difference is ontological. ${ }^{7}$ Wholes are different kinds of things from the parts that make them up, just as syllables are different from (but not in any straightforward sense more than) the letters that make them up. This is

4 'Hylo-' from hylē (Aristotle's neologism for matter) and '-morphism' from morphē (or form). There is substantial literature on Aristotle's hylomorphism (a word Aristotle himself never uses) and its more recent revivals. Good surveys of the idea and issues surrounding it can be found in Peramatzis (2018), and the Stanford Encyclopedia articles by Ainsworth (2016), Cohen (2016) and Shields (2016). For contemporary defences, see Scaltas (1994), Koslicki (1998, 2006, 2018), Marmodoro (2013).

5 Aristotle, Physics (Arist. Phys.) 2.3, 195a15-21; Metaph. 5.2, 1013b17-23.

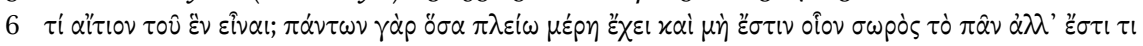

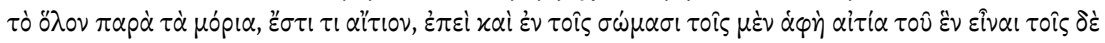

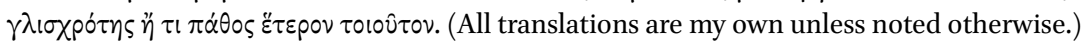

7 Heider (1977) 383 . 
something Aristotle argues for explicitly at Metaphysics $7.17,1041 \mathrm{~b} 11-42 \mathrm{a2} .{ }^{8}$ He believes that if we were to think that wholes are greater than their parts (or greater than their 'elements', as Aristotle refers to them here), then we run into a problem. If, for example, the syllable BA were greater than the sum of its parts, $\mathrm{B}$ and $\mathrm{A}$, then something would need to have been added to make it greater. The whole, therefore, is presumably B $+\mathrm{A}+\mathrm{X}$. Now, however, we need something else to explain why $\mathrm{B}, \mathrm{A}$ and $\mathrm{X}$ form a whole, and so we would need to posit another part to get $\mathrm{B}+\mathrm{A}+\mathrm{X}+\mathrm{Y}$, a process that would go on ad infinitum. Aristotle thinks such a regress is hopeless and so he argues that wholes are not created by adding something. ${ }^{9}$ Instead, there must be some other kind

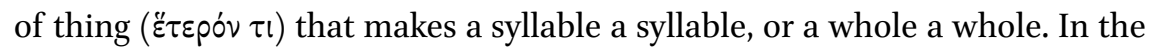
example of the syllable BA, this other kind of thing will be whatever it is that causes the elements B and A to be the syllable BA and Aristotle indicates two causes that fit the bill: one, the arrangement of the letter $B$ (or the sound ' $\mathrm{B}$ ') before the letter A (or the sound ' $\mathrm{A}$ ') - what he calls the formal cause; the other, the person or agent who places the $\mathrm{B}$ before the $\mathrm{A}$, what he calls the efficient cause. The form and the agent which causes the elements to take on that form are different kinds of thing altogether. The form is a cause to the parts of their being a whole rather than a heap; while the agent is a cause to the parts of their becoming a particular thing and so of the form and the matter becoming one. ${ }^{10}$

Arist. Metaph. 7.17, 1041b11-42a2: 'Since what is compounded out of something in such a way that the totality is one, not like a heap, but like the syllable - the syllable is not the letters, nor are B and A identical to BA, nor is flesh fire and earth (...); the syllable therefore is something, not only the letters (the vowel and the consonant), but also something else;

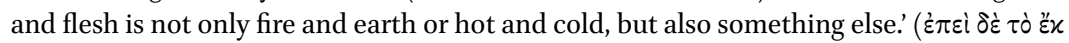

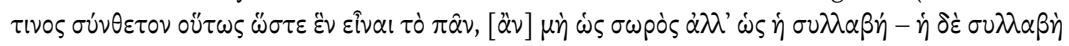

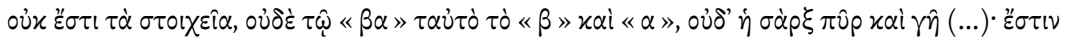

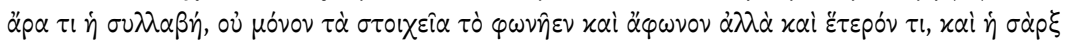

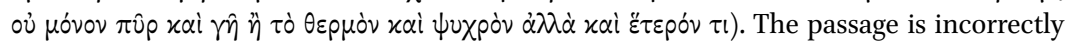
interpreted as stating the whole is more than the sum of its parts in the translation by Adolf Lasson (1907) 129: 'Das was aus Bestandteilen so zusammengesetzt ist, dass es ein einheitliches Ganzes bildet, nicht nach Art eines Haufens, sondern wie eine Silbe, das ist offenbar mehr als bloß die Summe seiner Bestandteile.' Again, Aristotle seems to be taking up themes from the Theaetetus. See n. 2 above.

9 On this, see Menn (2001) 125-34. I avoid for the purposes of this paper the question equally perplexing to Scotus and Ockham as to contemporary metaphysicians - of how matter and form, conceived as parts of the form-matter composite (the hylomorphic

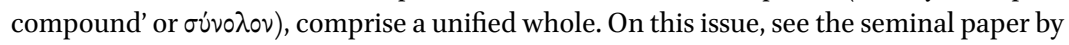
Ackrill (1972/3); for contemporary philosophical approaches, see Fine (1999) and (2010), Johnston (2006), Koslicki (2008); on Medieval approaches, e.g. Cross (1999) and Ward (2014); on its relevance to holism and the notion of sympathy, see Holmes in this volume.

10 Cf. Arist. Metaph. 8.6, 1045b2o-23; Phys. 2.3, 194b16-32 (where they are called causes of generation and corruption, not being and becoming - thanks to David Ebrey for pointing 
The account I have just sketched - or something close to it - is what people normally have in mind when they think about Aristotle's relationship to holism. Wholes are not just their parts, they are also their forms, and while we might think things are composed of matter and form, forms are not, at least in any straightforward sense, another part of a thing. Rather, they are a special kind of cause, which confers to the parts their being and unity. Aristotle famously refers to this kind of cause as ousia or substance. The story I wish to tell

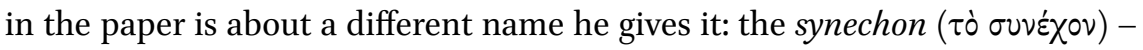
that which holds things together.

The idea that there is a kind of cause responsible for holding things together and whose weakening or dissolution brings with it disease and decay appears often in ancient philosophy and medicine. The cause itself goes by many different names. ${ }^{11}$ It is, however, perhaps most commonly associated with the Stoics.

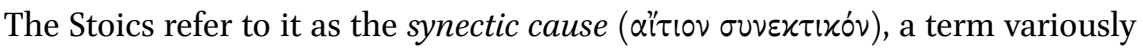
translated as 'cohesive cause,' 'containing cause' or 'sustaining cause,' although none of these intuitively express in English what the Stoics meant (I will use 'cohesive'). For the Stoics, the cohesive cause is a body, namely pneuma ( $\pi \nu \varepsilon \hat{\mu} \mu \alpha)$, a mixture of fire and air, which is active within all things as a kind of binding movement or force. ${ }^{12}$ Now, Galen claims that 'the first philosophers of [his]

this out to me). Typically, this is expressed by saying that some agent causes what is potentially $\mathrm{F}$ (the matter) to be actually F. B and A are potentially BA, but they are also potentially $\mathrm{AB}$ or perhaps even $\mathrm{ABBA}$. Aristotle thinks that the cause of the letters being actually $\mathrm{BA}$, instead of just being able to be BA, is their substance or formal cause, while the cause of the letters taking on the form, of actually becoming BA, is the agent or efficient cause. While it is an understatement to say the distinction between being potentially and being actually is important for Aristotle's metaphysics, it does not have much of a place in the story I tell here.

11 Galen gives a good summary of synonyms for the term: 'the cause that holds together

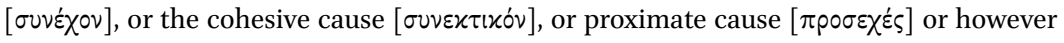
one might wish to call it ...' (Galen, De symptomatum causis 1.5, VII.109.7-10 K.). Philip van der Eijk points out to me that the author of the treatise Fevers, attributed to Alexander of

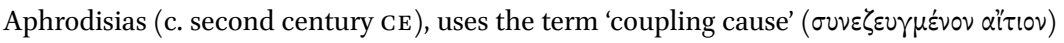
(ps.-Alexander, De febribus 27.1-12, 22,8-24,24 Tassinari). I discuss other terms in what follows.

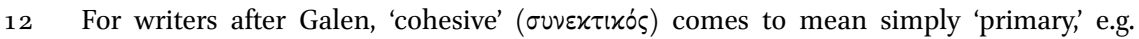
Simplicius: '(Aristotle) says 'highest cause' in the sense of 'what is most properly (a cause),'

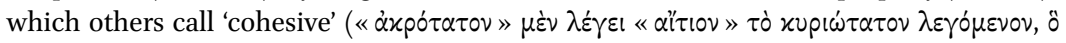

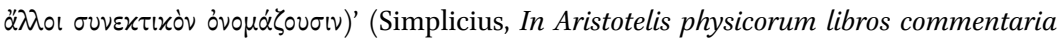
(Simpl. in Arist. Phys.) 9.326,13-21 Diels, ad Arist. Phys. 2.3, 195b21). It is important to note that by calling it a force, I do not imply that it is non-bodily or immaterial. For the Stoics, forces were bodies, insofar as anything that acts or is acted upon must, for them, be a body; this is not so foreign, as forces continue to be conceived of as bodies, e.g. gluons, photons and bosons more generally. 
acquaintance to speak of a cohesive cause were the Stoics,' and something like Galen's view of the history of the concept continues to be held today. ${ }^{13}$ The consensus among scholars today is roughly that the Stoics introduce the cohesive cause as an active, corporeal analogue of the Aristotelian form: Aristotelian forms and Stoic cohesive causes explain what something is, why it acts the way it does and why it persists as that thing, while the Stoic innovation is to understand this cause as a kind of bodily (but perhaps non-material) force binding things together as a whole. ${ }^{14}$ I think, however, that Galen's claim that this is a Stoic innovation is potentially misleading. Once we see that Aristotle's synechon and the Stoic cohesive cause are both answers to the question, 'what actively holds the parts of a whole together?', then it becomes clear that they are more than analogues. In fact, the Aristotelian synechon and the Stoic cohesive cause refer to the same thing: the nature or soul (the Stoics also add 'cohesion' ( $\xi_{\xi}(\varsigma)$, which is more or less an Aristotelian inanimate nature) understood as an internal principle of motion and rest. Aristotle believes this nature or soul is an immaterial yet substantial unmoved mover - an agent that always acts in the same way to produce the same kind of activity in the parts that make what it is. The Stoics believe that this (cohesion or) nature or soul is pneuma, an active, self-moving corporeal cause which interpenetrates and binds the passive material into a whole through what the Stoics call its 'tensional movement.' The Stoics' answer to the question 'what holds things together' might, therefore, more closely resemble Plato's self-moving world-soul in the Timaeus than the unmoved souls of Aristotle's De anima. Nevertheless, Aristotle and the Stoics both believe that a thing's parts are bound together by a kind of internal, active cause that is not an additional part.

Plato, Aristotle and the Stoics offer refined notions of the synechon in response to what they see as inadequacies in earlier attempts to explain how parts might form a whole. Their responses, however, were not the only ones possible. Democritus seems simply to have rejected the idea of wholes altogether, suggesting they are figments of the imagination. ${ }^{15}$ Alcmaeon of Croton

13 Galen, De causis contentivis (Gal. CC) 1.1 (52,1-2 Lyons); Adversus Iulianum 6.13 (XVIIIA.279-80 K. = 57,15-58,6 Wenkebach); Synopsis librorum suorum de pulsibus (IX.458.8-14 K.). Cf. Frede (1987) 145. Susan Bobzien (1999) 228 argues (more precisely) that the term is a later Stoic invention and not found in Chrysippus.

14 See e.g. Frede (1987) 145; Long and Sedley (1987) 340-41; Hankinson (1998) 240-41; Bobzien (1999) 229. These authors all seem to rely on the same testimony of Galen. I return to this below. On cohesive causes as things other than agents, but still causes of effects, see Hankinson (1987) 81-85.

15 Simplicius, In Aristotelis De caelo commentaria (Simpl. in Airst. De cael.) 295,1-14 Heiberg = Democritus 68 A 37 DK. 
believed cohesion resulted from an equipollence of opposing powers among the parts, and a similar view is found in Galen's criticism of the Stoic notion of a cohesive cause. The first thinker, however, who is reported to have talked about something like a cohesive cause is not a Hellenistic Stoic, but the sixth-century BCE Ionian physicist Anaximenes. After him, different candidates for the synechon are proposed by different philosophers and doctors, including Empedocles, some early Greek (i.e. Hippocratic) medical writers, and Diogenes of Apollonia. In what follows, I proceed by looking at these various thinkers' proposals - the early Greek philosophers and doctors, and also Plato, Aristotle and the Stoics -, how they think they bind the parts of a thing into a whole and the problems these proposals raised. I think there is something important gained by examining this history, even though it means I have to leave aside many details and that, given the nature of some of our evidence, the account I give will at times be speculative. The views of the Stoics in particular need more careful treatment than what I can provide here (the school was hardly united on this issue).${ }^{16}$ Still, I think this approach offers a productive way of thinking about the history of wholes, active causes and cohesion, of which Aristotle is a part.

Early Greek Philosophers and Physicians

I begin this story with the earliest accounts of bodily cohesion in Greek philosophy. Many philosophers and doctors before Aristotle explain how the parts of something are bound together into a whole, and one of their common strategies is to posit some special kind of part, a synechon (or related term), which holds the other parts together. The idea is intuitive. Glue, nails, fasteners, thread, etc., are all what we might call 'binding parts': bodies that hold something together, while at the same time being a part of it. Early Greek philosophers posited such binding parts to explain the unity of things, from simple solid bodies to the cosmos itself.

A familiar example of this kind of thinking is Empedocles' Love ( $\Phi$ เ $\lambda$ ótns). Love in Empedocles' cosmology is a hypostatized notion of a unifier - that

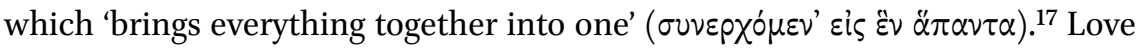

16 Frede (1987) remains the best entry point to these issues in Stoic philosophy. In this paper, I avoid discussions of determinism and responsibility as motivations for the Stoic theory of causes. I also will not be discussing Cicero's report of Chrysippus' causal distinctions at De fato 41-43, which I think raises more questions than it answers.

17 Simpl. in Arist. Phys. 9.158,7 Diels = Empedocles 31 B 17 DK. An anonymous reviewer points out to me that unity is not the same as holism: both Love and Strife result in wholes, either 
works in opposition to the great cosmic 'Strife' (Nعix०५), which Empedocles thinks is responsible for separating the cosmic elements out into different kinds, fire, air, water and earth. This cosmogonic requirement of difference and sameness, narrated as separation and unification, is already anticipated in early Greek mythology. In the Theogony, for example, Hesiod describes the birth of the cosmos as an act of divine separation: Kronos, son of Gaia (earth) and Ouranos (sky), separated the primordial gods by castrating Ouranos, who had forced himself on Gaia in perpetual sexual union, with an adamantine sickle. When Kronos later tossed Ouranos' genitals into the sea, Aphrodite,

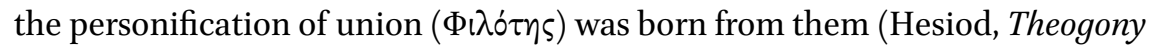
190-206; on Empedocles' identification of Love with Aphrodite, see Simpl. in Arist. Phys. 158,24 Diels = Emped. ${ }_{11}$ B 17 DK). The difference for Empedocles is that, like other physicists of the sixth and fifth centuries, he begins to think of the unifier as an element: something equiprimordial, bodily and able to extend throughout the cosmos (Arist. Metaph. 14.4, 1091b28), and which is able to determine what things are by becoming a part of them. ${ }^{18}$ Empedocles' Love does this by spreading out from the centre of the cosmos to its limits, becoming integrated into the mixtures of things it unifies (Simpl. in Arist. De cael. 529,1-15 = Emped. 31 B 35 DK, cf. Arist. Metaph. 1.4, 985a27-28). Other thinkers posit different cosmogonic elements and narratives. The pattern, however, at least in its general details, is the same.

When the synechon, like Empedocles' Love, is conceived of as a binding part, we find that it shows up at different levels of the cosmic hierarchy (in inanimate objects, in living things, in the cosmos as a whole); at all levels, however, binding parts share three general characteristics. First, they are conceived of as parts of the whole they compose; second, the whole depends on them in a different way than it depends on the other parts; and third, perhaps most important, they bring about wholeness by preventing the other parts from acting according to their own impulse. In other words, to form a whole or unity, a

by Love's uniting all the elements into one whole, or by Strife's uniting the elements into separate wholes; holism, however, arises somewhere in the middle, when the little wholes differentiated by Strife can work together to function as parts of a larger whole. The issue here is not whether Love is a synechon but whether it is the only one, since one could consider Strife to be what unifies the elements into separate wholes, a point already made by Aristotle in his criticism of Empedocles (Arist. Metaph. 1.4, 985a23-29), and who thinks Empedocles is confused. And it is interesting to note that, for Empedocles, cosmogony occurs between the complete rules of Love or Strife, and therefore holism results from both causes. Love, however, is still the cause of different things being unified, and so a more plausible candidate for the history of the synechon I am sketching here, even if Strife is the cause of the parts maintaining their distinctness as parts.

Menn (1995) treats many related issues here. My story is guided by his study. 
binding part needs to somehow overpower the other parts in order to compel them to maintain their arrangement.

The first characteristic of early theories of synechon is that what holds a whole together is a part of that thing. In the passage from Metaphysics 8.6 quoted earlier, Aristotle mentions stickiness ( $\gamma \lambda(\sigma \times p o ́ t \eta \varsigma)$ as a cause of bodily parts being a whole. This is not an idle example, but something Aristotle actually believes. As far as I can tell, the abstract noun 'stickiness' is first found in the writings of Aristotle and his student Theophrastus. Aristotle often, however,

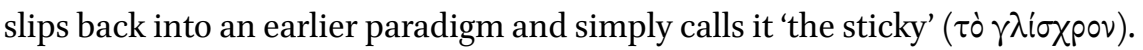
The difference is that 'the sticky' need not be an abstract entity, and Aristotle sometimes speaks of it as itself a part of the body (rather than as a quality of some part). At Generation of Animals 2.1, 737a36-b1, for instance, he em-

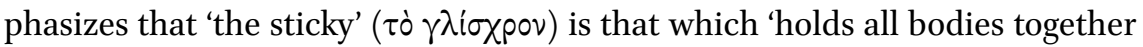
( $\pi \dot{\alpha} \nu \tau \alpha \delta \dot{\delta} \tau \dot{\alpha} \sigma \omega \dot{\omega} \mu \alpha \tau \alpha \sigma \nu v \varepsilon \dot{\chi} \chi \varepsilon l) .{ }^{19}$ And in the Aristotelian Problemata 21.6, 927b6-

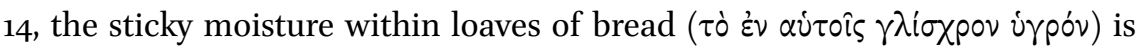
thought to be the reason why hot loaves of bread placed next to one another

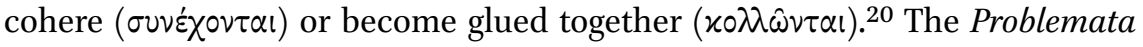
comes either from the time of Aristotle or not too long after, and it too continues to conceive of some synechonta as kinds of parts. The characteristic of parthood can also be inferred in thinkers earlier than Aristotle. Aristotle suggests that bodies that bring about cohesion were part of Empedocles' physics, and he emphasizes the similarities between Empedocles' views and his own.

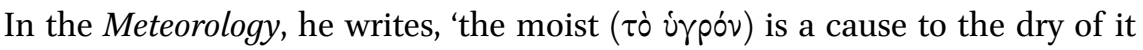

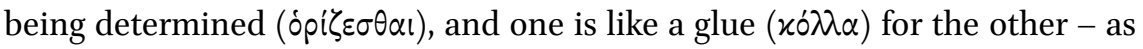
Empedocles wrote in his poem on Nature: 'gluing meal together with water'

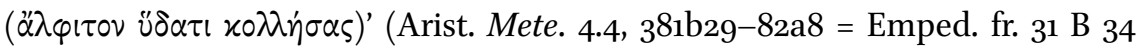
$\mathrm{DK}$ ). Empedocles is using glue as a metaphor here, but (at least according to Aristotle) the metaphor implies that he thinks the cohesion of a whole results from the composition of earth and water, where water is given the role of binding part. Aristotle agrees with Empedocles and he himself adopts this view in Generation and Corruption: 'the moist is what holds it (sc. the dry) to-

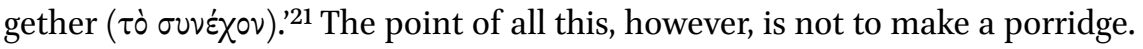
Empedocles and Aristotle are both saying that water or wetness is responsible

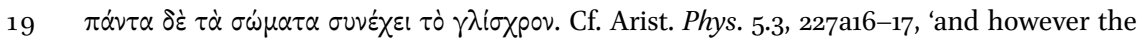

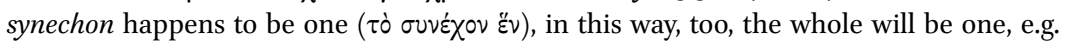

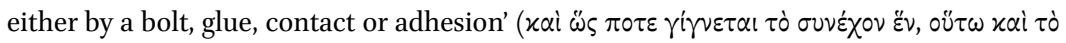

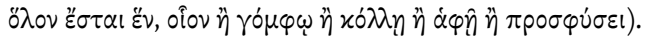

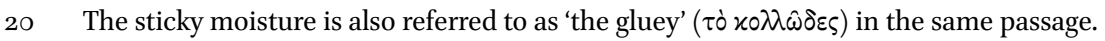

21 Cf. Aristotle, Generation and Corruption (Arist. Gen. corr.) 2.8, 334b3o-35a3: 'earth has no

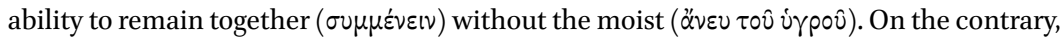


for the fact that solid bodies cohere, while the different proportions of water and earth, or wet and dry, will determine the different levels of cohesion. Too much fluid and a body will no longer be solid; too little fluid and the parts will not form a whole. There still remains the question of what determines these proportions. For Empedocles, it seems they are determined by a differ-

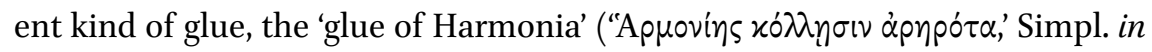
Arist. Phys. 300,24 Diels = Emped. fr. 31 B 96 DK), where Harmonia is, at least according to Simplicius, another of Empedocles' names for Love conceived, as before, as something actively binding things together. ${ }^{22}$ I will come back in the next section to what Aristotle thinks determines these proportions. For now, it is enough to say that water causes the cohesion of solid bodies by becoming, along with earth or the dry, a part of them.

The second characteristic of the synechon conceived of as a binding part is that, so long as it remains present in a thing and maintains its own cohesion, then the whole which it causes to cohere will remain coherent. If, however, the synechon leaves or loses cohesion, the parts will cease to form a whole. This is the case with Empedocles' cosmos, which, when Love retreats from that which it had been mixed with previously, results in the parts dissociating. Similarly, when wood is completely burned and the water expelled from it, what is left behind is uncohesive ash. Or when there is a loss of cohesion in the sinews that hold a joint together, then the joint loses cohesion as well and can no longer function - an obvious point perhaps, but worth making nonetheless. It appears often among early Greek medical writers. For instance, the author of Instruments of Reduction writes that, among other bones, 'the verte-

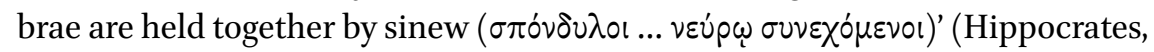
Leverage (Mochl.) 1, IV.342 L. = 246,9-11 Kühlewein); and the author of the second Prorrhetics writes about lameness caused by injuries that sever the 'sinews

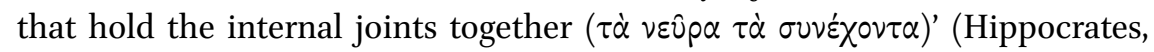
Prorrheticus II 15, IX.4O L. $=254,26-28$ Potter). The idea that there are bodily tissues like cords that hold us together is obvious enough, and like the earlier example of 'the sticky, the synechon as a bodily tissue is also adopted by

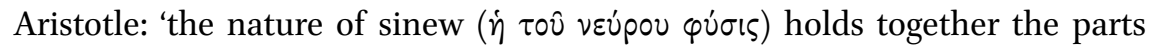

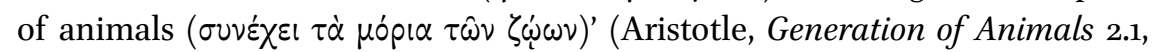
$\left.737 \mathrm{a} 34-\mathrm{b}_{7}\right) \cdot{ }^{23}$ Reflection on this aspect of the synechon may have led later

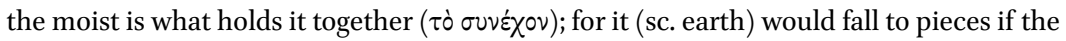
moist were eliminated from it completely.'

22 Many thanks to Gábor Betegh for pointing me to this passage.

23 Some scholars excise this passage. The passage shares affinities with the Hippocratic work Fleshes: 'that, on the other hand, which happened to be more gluey [ to contain cold, could not be burnt up on being heated or become dry, [...] for this reason 
thinkers to define cohesive causes as causes such that when they are present the effect is present and when they are absent the effect is absent.. ${ }^{24}$ This aspect will become central to debates about cohesive causes in ancient medicine from Erasistratus (third century $\mathrm{BCE}$ ) onwards, where the notion of cohesive causes is extended to all causes that are contemporaneous with their effects, but most importantly, from a medical point of view, to causes of disease, e.g. that thing which is, right now, causing disease, like a kidney stone, as opposed to that thing which, at some earlier point in time, did something which later led to disease, like a bite from a dog. ${ }^{25}$ In our case, while the parts remain what they are even when the synechon and the whole do not exist, the existence of the whole requires the simultaneous existence and presence of the synechon.

The last characteristic of the synechon I want to look at is its role as a 'preventer' ( $\tau \dot{0} x \omega \lambda \hat{o v}$ ): something which checks or hinders the tendencies of the other parts that comprise the whole. Early Greek physicists believed that there are basic, unchanging elements that have (or just are) tendencies or powers, and they needed some story to tell about what it is that prevents the different parts from either separating out or collapsing. Clay may be a mixture of fire and earth, but fire tends to go up, earth to go down, and clay does not routinely fly apart. The sky and the earth may both be made of things that have weight and so tend to fall, but, at least for now, the sky has not fallen. With the products of human craft, one can say, e.g., that the pillars hold up the roof, or the glue holds the joints. Different options were offered for what serves the analogous preventing or hindering function in nature.

It will take a little work to present the evidence, but at least according to Plato and Aristotle, one of the earliest figures to think of the synechon along these lines was Diogenes of Apollonia. There is some evidence that before Diogenes, the Ionian physicist Anaximenes did so as well. Some sources report that Anaximenes argued that, as our soul is a kind of air that holds us

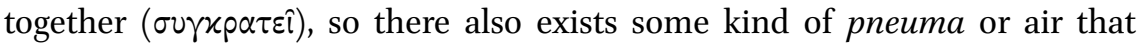

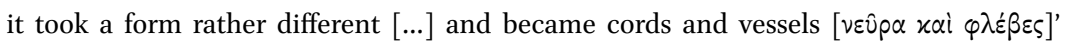
(Hippocrates, De carnibus (Hipp. Carn.) 3, VIII.586 L. = 134.6-18 Potter, tr. Potter, modified). Aristotle, too, thinks the vessels hold the body together. See Arist. Part. an. 3.6, $668 \mathrm{~b} 20-27$. The shell is the analogue of cords and vessels in non-blooded animals. See Arist. Part. an. 2.8, 654a3-8.

24 On this, see Frede (1987) 146-47, Bobzien (1999), and the excellent discussions in Hankinson (1998) 376-79 and Havrda (2016) 262-73, 306.

25 For the debate, see Gal. CC 2.1 (55,6-11 Lyons); Adversus Iulianum 6.13 (XVIIIA.279-80 K. = 57,15-58,6 Wenkebach). For examples, see Ps.-Galen, Introductio sive Medicus ([Gal.] Int.) 8 (XIV.691-92 K. = 16,9-24 Petit); ps.-Galen, Definitiones medicae ([Gal.] Def.) 157; XIX.392-93 K.; Sextus, Pyrrhoniae hypotyposes (S. E. PH) 3.15; Clement, Stromata 8.33.1-7 (101,16-102,16 Havrda). 


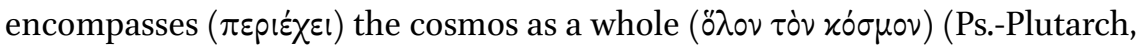
Placita, 876 a10-12 $=$ Anaximenes $13 \mathrm{~B} 2 \mathrm{DK}) .{ }^{26}$ If this fragment is authentic, then it is the earliest explicit reference to the soul being that which holds the body together, as opposed to some other part like sinews or bones. It is also one of the first places where we find parallel cohesive entities mentioned at micro- and macrocosmic levels. Yet the authenticity of the fragment is at best dubious; instead, the earliest point at which we can reliably say the synechon becomes an object of philosophical reflection is in response to the works of Diogenes of Apollonia.

Diogenes is an eclectic thinker, who combines ideas from Anaximenes, Heraclitus, Anaxagoras and Leucippus. He attempts to update the theories of an earlier generation, which posited a single material principle from which everything arose, and he is especially fond of Anaximenes, agreeing with him that everything in the cosmos derives from air and is moved by air and that our soul, which animates us and moves us, is also a portion of cosmic air contained within our body. He combines this old-fashioned view with the new physics of Anaxagoras, who posited a special kind of stuff called reason (vovs), which he thinks permeates all things and is responsible for moving the other bodies in a rational way to form a cosmos. Anaxagoras believed that vov̂s, which is 'the absolute ruler ( $\alpha \dot{\tau} \tau o x p \alpha \tau \dot{\varepsilon} \varsigma)$ ', must be 'unmixed with any of the other stuff

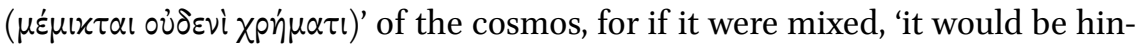

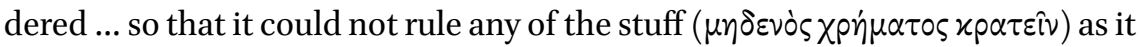
now does being alone by itself' (Simpl. in Arist. Phys. 156,13-15 = Anaxagoras 48 B 12 DK). Diogenes agrees with Anaxagoras that the fact that the cosmos is intelligible and well-ordered needs to be explained by proposing a rational cause of order - and what better cause of rational order than hypostatized reason itself? He thinks, however, that reason is not independent of all the other stuff, but is instead to be identified with air, which he thinks possesses thinking (von'øs). The air, therefore, is the source of movement in the cosmos, while its thought is the source of the order of that movement. ${ }^{27}$ We can speculate that

26 There is a great deal of uncertainty both about the reliability and the interpretation of this

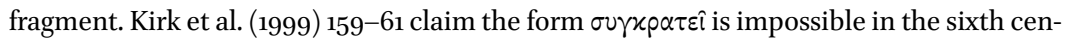
tury. They are likely correct. A search of the TLG shows no use before the late Hellenistic

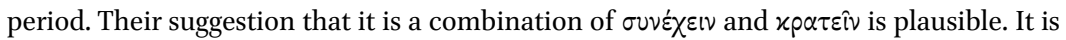
possibly Stoic: see its uses at [Plut.] Plac. 14, 907a8 and [Gal.] Def. 96, XIX.372 K., the latter

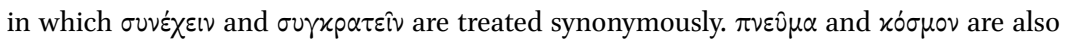
unlikely in Anaximenes' time. On this, see also Vlastos (1955) 363-64 and n. 56.

27 This account broadly follows Menn (1995). Cf. Simpl. in Arist. Phys. 152,13-22 = Diogenes 64 B 3-4 DK. Intelligence is attributed to air by the author of The Sacred Disease, but whether the author identifies them is unclear to me. See e.g. Hippocrates, De morbo sacro 19 
Diogenes believes the advantage of this kind of account is that rationality in us and the cosmos, as well as life and movement, are explained by the same entity.

In a fragment from his On Nature preserved by Simplicius, Diogenes writes that air:

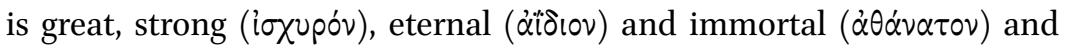

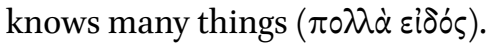

Simpl. in Arist. Phys. 153,21-2 = Diogenes of Apollonia 64 B 8 DK

What Diogenes means by claiming air is strong (i゚Xupóv) is not immediately clear from the fragment, but parallels of this fragment in Plato and Aristotle can at least tell us how they understood him. For Plato and Aristotle, the strength of air refers to its role as a synechon, and they took Diogenes to be saying that it exercised its role as a synechon by hindering the impulses of other bodies. The first passage is in Plato's Phaedo, and although Diogenes is not named, the similarity to the fragment above is suggestive of the fact that Plato has Diogenes' On Nature in mind. He writes that the physicists

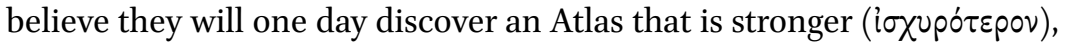
more immortal ( $\dot{\alpha} \theta \alpha \nu \alpha \tau \dot{\omega} \tau \varepsilon \rho \circ)$ and better able to hold everything to-

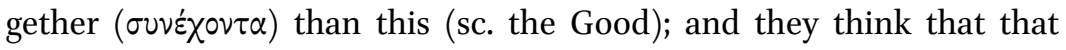

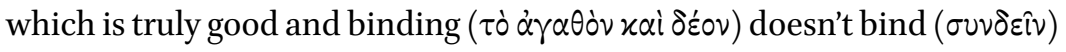
and hold together ( $\sigma u v \varepsilon \dot{\chi} \varepsilon \varepsilon v$ ) anything.

PLATO, Phaedo 99c2-6 $6^{28}$

If this is a representation of Diogenes' views, then Plato thinks that Diogenes is talking about the synechon in On Nature. Plato goes so far as to call the synechon Atlas: a Titan strong enough to hold the cosmos together. ${ }^{29}$

(VI.39o L.). The author of the Hippocratic Fleshes, however, attributes almost an identical set of properties to 'heat' ( $\tau \dot{\partial} \theta \varepsilon p \mu o ́ v)$ at Hipp. Carn. 2 (VIII.584 L.).

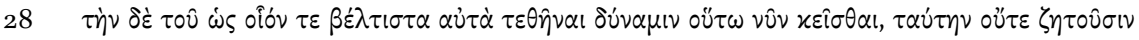

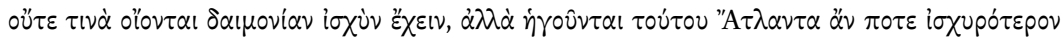

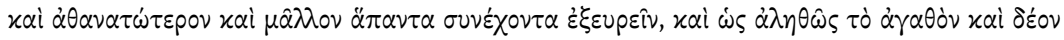

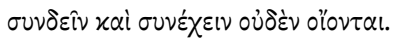

29 Why the Titan Atlas? David Ebrey suggests to me that Plato may be contrasting the earth-born Titan with notions of Olympian divinity. It is possible, moreover, that some physicist used Atlas illustratively, but we do not know which one. See next passage. Also similar is the Hippocratic Breaths: Hippocrates, De flatibus 4 (VI.96 L. = 93,18-19 Heiberg) and ${ }_{15}$ (VI.114 L. $=101,16-23$ Heiberg). On Diogenes as a common source for both Plato and the author of Breaths, see Menn (1995) 39-41. 
The second parallel is from Aristotle's Metaphysics 5.23, and this passage makes the connection between the synechon and the 'preventer' explicit. Aristotle writes:

That which prevents ( $\tau \dot{\partial} x \omega \lambda \hat{\nu} \circ)$ ) something from moving or acting in accordance with its own impulse is said 'to hold it' (है $\chi \varepsilon \varepsilon v)$, as e.g. pillars 'hold' ( $\varepsilon^{\prime} \chi \varepsilon(v)$ the weights lying upon them and as the poets make Atlas 'hold' ( $\left.\varepsilon^{\prime} \chi \varepsilon i v\right)$ the sky, since it would fall upon the earth, just as some of the

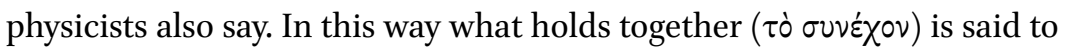

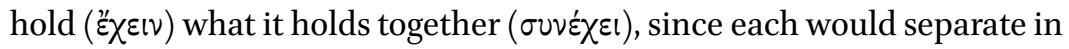
accordance with their own impulse.

ARIST. Metaph. 5.23, 1023a17-23 30

According to Aristotle, one way of understanding the synechon is as that which prevents ( $\tau \dot{0} x \omega \lambda \hat{o v}$ ) the parts from acting according to their own impulses. The sky, for instance, left to its own impulses, would fall to the earth; ${ }^{31}$ but, as long as it is held up by Atlas and as long as Atlas can overpower the tendency of the sky to fall, the cosmos will be sustained. ${ }^{32}$ In the same way, the synechon prevents the parts of a thing from separating out. The assumption, then, is that the parts of things have impulses, which on their own would lead them to separate out; since wholes exist, those impulses must somehow be restrained. The synechon is the name given to whatever it is that does this.

The model of the synechon of the early Greek physicists is, we might say, tyrannical, at least as it is understood by Plato and Aristotle. The synechon is a distinct kind of part which holds things together, what I have called a binding

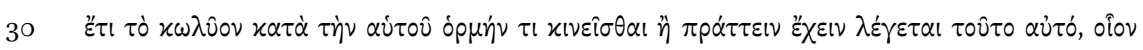

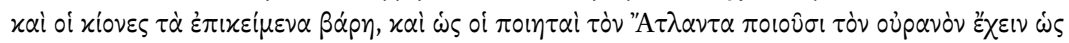

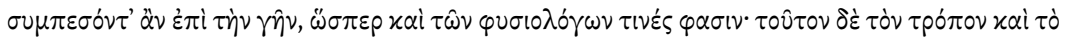

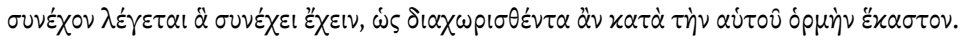

31 Diogenes is reported to think it sometimes does fall as meteorites. See Aetius Placita 2.13.15 and $9=$ no. 608 Kirk et al. (1999) 445 .

32 One might object that Atlas is clearly keeping things apart, rather than holding them together, and the variation between Plato's and Aristotle's terminology, where Plato says

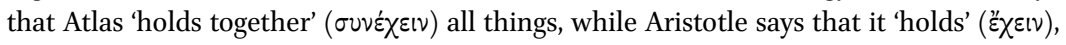
suggests the terminology was not settled. The general agreement, however, is that the synechon holds things together by being stronger than the things it holds together and restraining the parts that make up the whole. 
part, and it does this by overpowering the tendencies or impulses of the other parts. ${ }^{33} \mathrm{~A}$ whole is made up of competing forces, subdued by the strength of a dominant force, compelling and forcing them to unite as one.

The tyrannical model of the synechon we find in Diogenes is adopted and refined by both Plato and Aristotle (I will turn to Aristotle in the next section). In the passage from the Phaedo above, Plato complains that they 'think that that

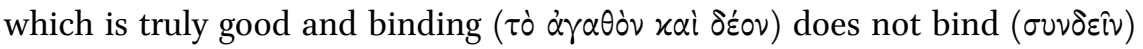

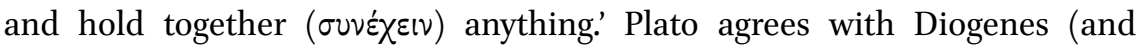
Anaxagoras, Empedocles and the others), that intelligence or the good should be that which holds the cosmos together, but he thinks this needs a different kind of model of cohesion, one that does not unite parts into a whole merely through force and compulsion, but under a common virtue or good. Plato has Socrates make a similar point in the Gorgias: 'the wise say that fellowship and

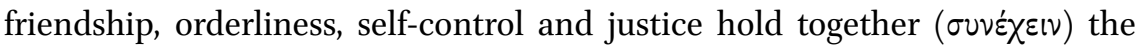
heaven and earth, gods and men, and because of these things, my friend, they

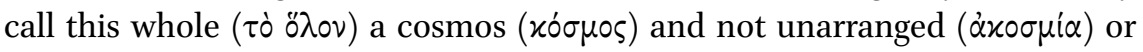
uncontrolled ( $\left.\dot{\alpha} \times 0 \lambda \alpha \sigma^{\prime} \alpha\right)^{\prime}$ ' (Plato, Gorgias, $\left.507 \mathrm{e} 6-8 \mathrm{a} 4\right) \cdot{ }^{34}$ At this level of abstraction, the point is not idle. If the parts of a whole share a unity of purpose, such that they are directed towards achieving one good, then Plato thinks such an entity has a better claim to being a whole than if it were merely assembled by force.

Why Plato thinks this is not entirely clear, but there have been some suggestions. In an article on Socrates' objections to the earlier physicists in the Phaedo, Stephen Menn points out that one thing Plato might be criticizing is the failure of materialist accounts like Diogenes' to explain why things are

So, in Euripides, Supplices 311-14:

... and all those who confuse the customs of Hellas,

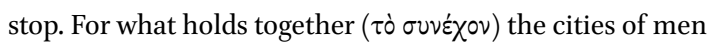

is this: when someone rightly preserves $\left(\sigma \dot{\omega} \zeta_{\eta}\right)$ the laws.

Alexander of Aphrodisias thinks Aristotle was trying to avoid this implication, claiming the difference between the way a tyrant 'holds' a city and the synechon 'holds' a whole, is that a tyrant imposes his impulse on things, while the synechon prevents other things from acting according to their impulse (Alexander, In Aristotelis Metaphysica commentaria 421,17-21 Hayduck).

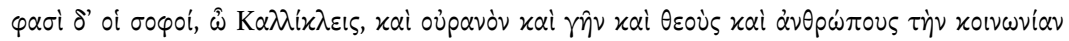

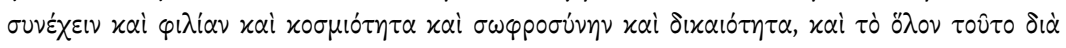

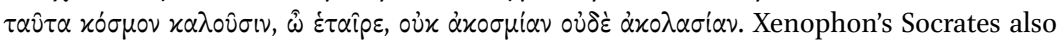

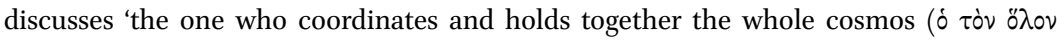

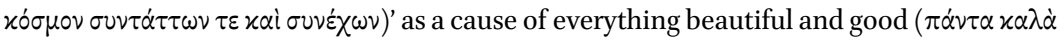
xai $\alpha \gamma \alpha \theta \dot{\alpha}$ ) (Xenophon, Memorabilia, 4.3.13). 
wholes at all. ${ }^{35} \mathrm{~A}$ mass of things held together by compulsion may have spatial contiguity, but this would not be enough to get us substantial or conceptual unity, since it leaves unexplained the most important fact about it: that it is a whole, a single subject, with parts that have the arrangement, or cosmos, they have. To explain that there is a single thing, we need a different kind of synechon, something unlike air or the other kinds of material things which the tyrannical model assumes.

In addition to this conceptual problem, Plato may also believe that it is implausible to consider the kinds of things Diogenes or Anaxagoras posit to be sources of orderly, rational movement in other things. Plato believes, and thinks his interlocutors believe as well, that all perceptible things share one feature: water, earth, even Diogenes' air, Anaxagoras' Reason, or Empedocles' Love, move by contact: by moving and being moved by other things. ${ }^{36}$ This may be why Plato says the physicists are looking for an Atlas stronger than the bodies it compels and also why he thinks these projects are bound to fail. If bodies move by being moved, then when Atlas pushes up against the sky to hold it, the sky will push back against him. For Plato, however, such an arrangement is implausible: no matter how rational Atlas is, as long as he is a body, he will be moved by the things he is moving contrary to his reason. Given a long enough time, perhaps the cosmos might descend into disorder, ${ }^{37}$ or perhaps this is too impious a position to attribute to a divine cause of order. But whatever Plato's precise reason, the cosmos is not disorderly, and so he thinks what holds the cosmos together must be an even more absolute ruler than Diogenes' tyrant, one which can hold the cosmos together without its authority being threatened. To do this, it needs to be a different kind of thing altogether, some entity that can bring about an effect in the parts and preserve the whole they compose, without itself being subject to change from the things it is acting upon.

To conclude this section, I think it is useful to compare Plato's revision of Diogenes' tyrannical model (we can call it the monarchic model) with a still earlier one, which appeals to another political metaphor - that of equality or isonomia. Its most famous proponent is Alcmaeon of Croton, who (at least according to the report) claimed, 'what is cohesive of health is the equality of

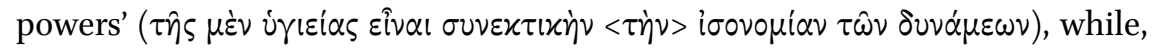
of diseases and corruption more generally, 'the agent is a monarchy among

$35 \quad$ Menn (2010) 53-61.

36 Plato develops these themes further in Timaeus 52a-e and Laws X 893b-99d.

37 Menn (1995) 41. This study continues to serve as a foundational introduction to Plato's critique and refinement of early Greek physics. 


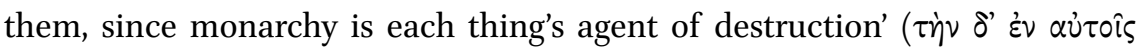

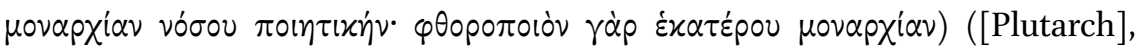
Placita philosophorum 30, 911a2-9 = Alcmaeon 14 B 4 DK). As Gregory Vlastos points out in 'Equality and Justice in Early Greek Cosmologies', for many early Greek physicists and physicians, including Alcmaeon, 'the order of nature is maintained because it is an order of equals. ${ }^{38}$ Rather than assuming there is one body or force which compels unity on parts to form a whole, this model assumes that cohesion is something that emerges from an equality or equipollence among opposing bodily forces. The same model of equality is found in some Hippocratic writers, who see the equal mixture ( in the body (e.g. hot cold moist dry) to be equivalent to health. It is also found in Plato's Phaedo as the view proposed by Simmias, who claims 'our body is as

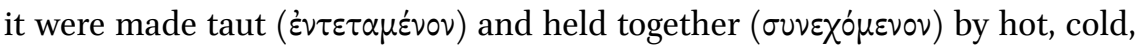
dry, wet, and things like them, and our soul is a mixture ( $\varkappa \hat{\alpha} \sigma / \varsigma)$ and harmonia or attunement ( $\dot{\alpha} p \mu o v i \alpha)$ of those same things' (Pl. Phd. 86b7-c1). ${ }^{39}$ The fact that the isonomia/mixture model is put forward by Simmias, with his apparent ties to Pythagoreanism, suggests the model may also be at work in theories in which the soul is conceived of as a harmonia, where the harmonia literally is the mixture or attunement of the constituent elements. ${ }^{40}$ The author of the text attributed to Alcmaeon in the Placita, of course, is himself stretching when he writes that Alcmaeon calls isonomia 'cohesive' of health and monarchy its agent of destruction. Alcmaeon almost certainly did not use the term

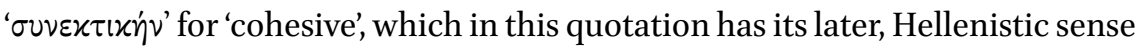
of a cause such that when it is present the effect is present. The author's interpretation nevertheless highlights what Alcmaeon and Simmias are suggesting, namely that coherence and unity emerge from an equipollence of opposing parts.

The idea that cohesion arises from an equality of opposing forces is about as far as one can get from Diogenes' tyrannical model of the synechon of liv-

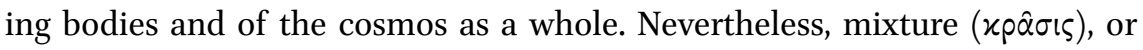
an equality of forces, remained a productive way of understanding material composition and cohesion. The physician Galen will go so far as to write a treatise in this tradition, That the Qualities of the Soul follow the Mixtures of the Body $(Q A M)$, which sets out to prove that the qualities of the soul depend on, and so emerge from, the mixture of elements in the body, thus suggesting that

\footnotetext{
$38 \quad$ Vlastos (1996) 58-61.

39 I am grateful to Gábor Betegh and David Ebrey for suggesting a connection with Simmias' claims in the Phaedo.

40 On Simmias' Pythagoreanism, see Sedley (1995).
} 
the body is what holds the soul together, rather than the other way around. ${ }^{41}$ Aristotle, however, took a different approach to the notion of mixture. He supposed, like Plato, that bodies cannot be causes of their own cohesion. This role must be filled by something else, some cause that is not another part, which Aristotle called nature or soul.

\section{$4 \quad$ Aristotle}

So far, I have claimed that the synechon of Plato's and Aristotle's predecessors share three characteristics, which I call the 'tyrannical' model of cohesion. The first is that the synechon is a part of what it holds together, what I call a binding part. The second, that the whole it holds together only exists so long as the synechon exists. And the third is that the synechon holds parts together by hindering the impulses of those parts. I have also argued that Plato criticized and refined two of these characteristics. Against the first characteristic, Plato argues that, at least at the level of living things and the cosmos as a whole, the synechon cannot be another part of the whole the same as other bodily parts. If it were, it would end up being jostled around too much by the things it is trying to hold together to plausibly maintain the order and integrity of the cosmos we observe. ${ }^{42}$ Against the third characteristic, Plato argues that the synechon, if it is to produce a whole, cannot merely be what hinders the impulses of the parts, but also needs to be what directs those impulses towards a common purpose. This may involve tempering or hindering the individual impulses, but what unifies them into a whole is not merely their being forced into some kind of contiguity, but the purpose to which they are being aimed.

I have also shown that at the bodily level, Aristotle continues to use the tyrannical model of cohesion presented by his predecessors. He thinks the

41 Galen, $Q A M(\mathrm{IV} .767-822 \mathrm{~K} .=32,1-79,24$ Müller). I cannot here do justice to the complexities around theories of mixture and their rise in Hellenistic and later thought. For an overview, see Singer et al. (2018) 1-46; and Mirrione (2017).

42 Plato does often talk about the soul in ways that make it seem similar to perceptible bodies, e.g. especially in the Timaeus, where he says it is something spatially extended and jostled around by the bodies it inhabits. As David Ebrey points out to me, this might imply souls as synechonta are subject to the same criticism - and this may be true, and perhaps even desired, since living things, unlike the cosmos, are not immortal, which they would be if what held them together could never be weakened. Plato needs to give other arguments in the Timaeus to explain why the cosmos is immortal, namely because there are no bodies outside of it which might impede its activity by acting on it from without. See Pl. Ti. 32c-34b. 
cohesion of things like chairs or animal bodies can be explained by the presence of binding parts like glue, rivets or sinews. At the same time, he agrees with Plato that if a whole is to be a true unity, then there needs to be some cause that unifies the parts more than spatially or by contact. There needs to be a unity of purpose, what Plato calls the good and Aristotle 'that for the sake of which' something exists. In this section, I want to focus on another model of bodily coherence which Aristotle uses to illustrate this kind of cause, namely the arts.

There are three passages in Aristotle's De anima where he addresses the question, what is it that actively holds the parts of the body together? In these passages, Aristotle uses the characteristics of the synechon accepted by his predecessors, including Plato, to argue for a different model of the synechon that is not based on the relation of a tyrant to what it rules or on an equipollence among opposing powers, but on the relation of an art to its instruments or organs.

In the first passage, Aristotle uses the argument from the Phaedo to show that the soul cannot be made up of several different elements, in other words, that the soul cannot arise, like health does for Alcmaeon, from several different elements combining.

Someone might also raise the problem: (if the soul is composed of dif-

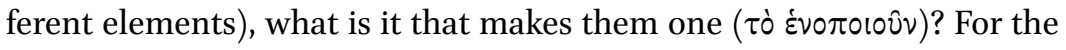
elements, at any rate, look like matter, while the synechon - whatever it is - is most powerful. But it is impossible for anything to be stronger than

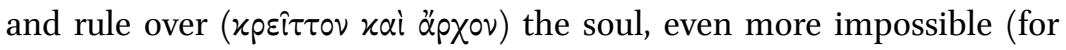
something to rule over) reason.

ARIST. De an. $1.5,410$ b1o-14 43

This argument is similar to the ones from Diogenes and Plato we met earlier, but Aristotle is extending those arguments from macro- to microcosm. Whatever the synechon is, whether it is a body or an immaterial substance or something else, it must be 'the most powerful,' i.e., more powerful than any of the things it is meant to hold together. Otherwise, it would not be able to hinder the impulses of the things it binds. And Aristotle, following the Phaedo, will argue that this means the synechon cannot be material: matter can always be moved, because it is always just as strong as any other matter. The synechon

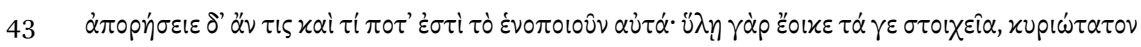

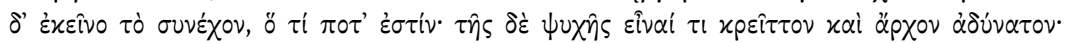

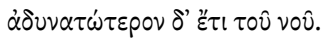


must instead be something that cannot be moved, at least by the things it binds, and so must be something immaterial, i.e. soul or reason.

Aristotle then turns to a slightly different question, namely what holds the parts of the soul together. This argument appeals to the second characteristic of the synechon, that the whole exists only so long as the synechon exists and is present in it. Aristotle uses it against an opponent who thinks the soul is naturally divided ( $\mu \varepsilon p 1 \sigma \tau \dot{\eta} \pi \varepsilon \dot{\varepsilon} \varphi x \varepsilon v$ ), asking what it is that holds the divided

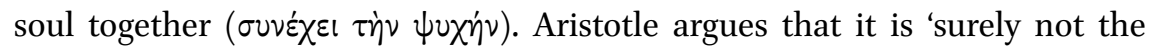

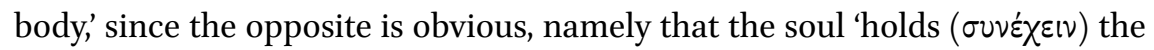
body together, since the body evaporates and putrefies when it departs' (Arist. De an. 1.5, 411b6-9). ${ }^{44}$ Aristotle's target here is almost certainly Plato. In the discussion of different kinds of soul at Timaeus $69 \mathrm{c}-73 \mathrm{~d}$, Plato has the lesser gods construct and localize the mortal kinds of soul in different regions of the body. When he goes on to explain how the different kinds of soul are bound together, including the immortal soul, he explains it by their common bond to the body: the god 'bound the kinds of souls together by implanting them

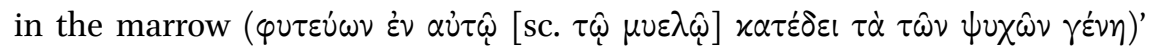
(Pl. Ti. $73 \mathrm{C} 3-4){ }^{45}$ Aristotle thinks this explanation cannot succeed. Even if only the immortal, i.e. intellectual, soul departs at death, the body nevertheless rots, and this implies that the other souls (or parts of soul) have departed as well. These souls must, therefore, form a whole and not merely because they are present in the same body.

The third passage contains Aristotle's own solution to the problem of the synechon of the body. Aristotle has been discussing Empedocles' explanation of why the roots of plants grow down and their tops grow up (answer: earth naturally tends to go down, fire tends to go up, and the growth of the plant spreads along this axis). After some initial criticisms, Aristotle asks:

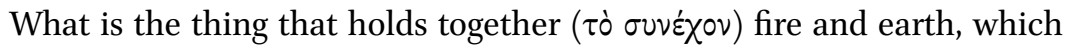
tend to move in opposite directions? For they will be pulled apart if there is nothing preventing it ( $\tau \dot{\partial} x \omega \lambda \hat{v} \circ \nu)$. But if there is, then this is the soul and the cause of nutrition and growth. Some people think the nature of fire is the cause of nutrition and growth, especially since it is the only body that seems to be fed and to grow, and for this reason someone might assume,

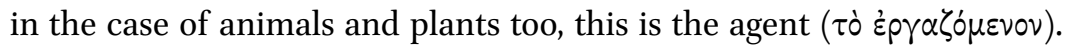

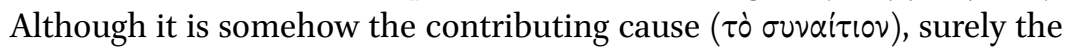

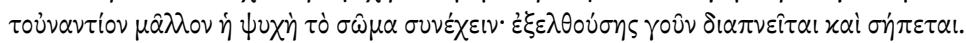


cause ( $\tau$ ò ali iov) strictly speaking is not (fire), but rather the soul: for fire's growth is unlimited as long as there is something to burn, while of things composed by nature, there is a limit and proportion of both size and growth. These belong to soul rather than fire and to reason ( $\lambda$ óros) rather than matter.

ARIST. De an. 2.4, 416a6-18 $8^{46}$

Aristotle begins this passage by appealing to the synechon's role as that which prevents the parts from separating according to their own impulses. The target is Empedocles and his attempt to explain the growth of plants according to the elements (the parts) that make them up. Aristotle's point is that Empedocles' strategy of trying to explain the activities of a whole in terms of the activities of the parts is hopeless, especially since those parts have opposing impulses, which, rather than leading to a complex activity and arrangement, as we in fact find, should simply lead to the plant being torn apart. Aristotle does not want to deny that the powers of the elements have a role in the growth and maintenance of a living thing; but he wants to reconsider what that role is in light of the fact that the elements cannot explain the arrangement and limit

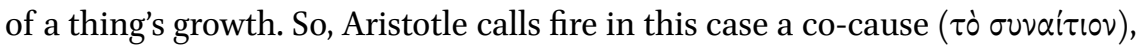

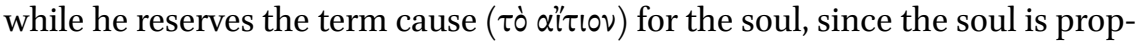
erly speaking the agent ( $\left.\tau \dot{\delta} \dot{\varepsilon} p \gamma \alpha \zeta \zeta^{\prime} \mu \varepsilon v o v\right)$ acting in accordance with a rational

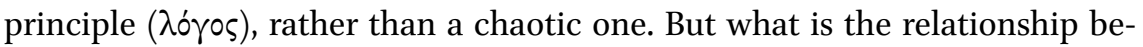
tween the two?

Aristotle appeals to a different model of the synechon from that of a tyrant or monarch, opting instead for a model based on the arts. In broad strokes, Aristotle thinks that, among living things, what makes them wholes is not a specific material part, but the soul, which actively holds the parts of the body together. The soul does this not by constraint or force, but by producing and maintaining the various parts of the body through nutrition and growth, an activity which uses the body and its components as instruments or organs (in Greek, $\tau \dot{\alpha}$ öpr $\alpha \nu \alpha)$. What guarantees the cohesion of the body in this instance is the fact that the body is a prerequisite for the soul to do whatever else it does

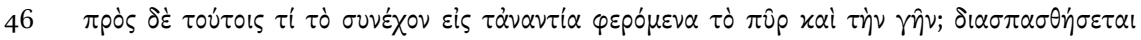

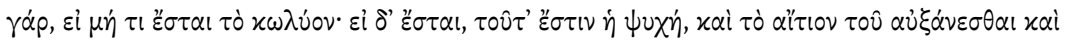

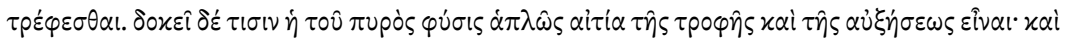

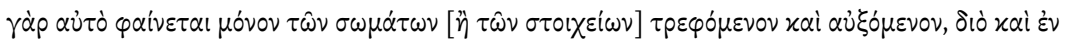

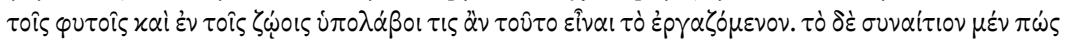

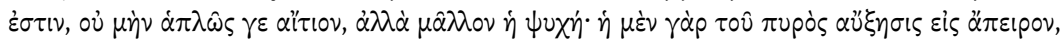

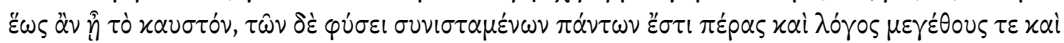

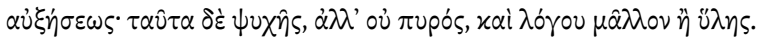


(reproduce, perceive, think). So long as the soul is present in the body, it will actively maintain the arrangement of the body in order that the body continues to serve as its instrument.

Aristotle does not use this model to suggest that the soul is like an artist using instruments; rather, he seems to be thinking of the soul like an art using its instruments. ${ }^{47}$ The muses may always need a poet, but nature needs no such medium - it can act immediately through bodies. This leads Aristotle to make some bizarre-sounding claims. He says things like, 'if the art of ship-building were in the wood, it would produce the same results by nature' (Arist. Phys. 2.8, 199b28-29), i.e. the wood would turn itself into a ship. There is also a thought experiment about an axe as a natural body $(\varphi v \sigma i x \dot{\partial} v \sigma \hat{\omega} \mu \alpha)$, something like

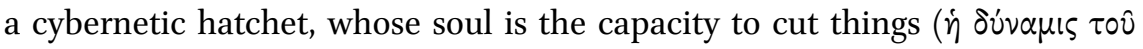
ópróvov) and whose activity is to get up and cut things on its own, no carpenter required (Arist. De an. 2.1, 412b10-13aro). In the world of human craft, an artist is a necessary intermediary between the art and the instruments or organs through which it acts; nature, however, needs no intermediary. It operates

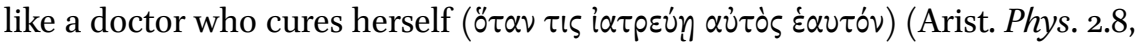
199b31).

That is not to say that outside influences cannot act on the body and threaten its cohesion. The soul may be unaffected or unmoved by the body when it acts, since like, the art of medicine ... when it produces health, it is in no way affected by the patient who is being healed' (Arist. Gen. Corr. 1.7, 324a35-b1). ${ }^{48}$ Nevertheless, the matter, i.e. the body, like food or a drug acting as instruments of the agent, is always affected when it carries out the soul's activities: 'the food, when it produces (health), is also affected in some way: for it is heated or cooled or otherwise affected at the same time as it acts' (Arist. Gen. Corr. 1.7, 324b1-3). Over time, the body, like a blunted instrument, will become incapable of carrying out the activities of the soul, including the activity of maintaining its own cohesion. ${ }^{49}$

47 Menn (2002) 95.

48 Cf. Arist. De an. 3.5, 430a17-19 'for reason ( $\delta$ vov̂s) is separate, unaffected and unmixed, being substance in actuality. For the agent is always more honourable than the patient, and the principle than the matter.' On the Gen. Corr. passage and its relevance, see Menn (2002) 95-99; Falcon (2005) 25.

49 Menn (2002) 113. 
The history of the synechon or cohesive cause which I have been tracing leads in the end to the more familiar Stoic notion. The Stoic position on cohesive causes resembles something like an eclectic mix of Diogenes of Apollonia and Aristotle. A comparatively large amount of literature exists on the Stoic theory of cohesive causes, at least much more than on earlier theories. ${ }^{50}$ Rather than rehearse this literature, I want to conclude by noting a few aspects of the Stoic notion of cohesive causes that seem to me most closely related to this earlier tradition.

The first is perhaps trivial, but worth mentioning. It is often said that the Stoic cohesive cause is an analogue to the Aristotelian form, ${ }^{51}$ but speaking this way tends to obscure how similar the causal role of the Stoic cohesive cause and its Aristotelian equivalents are, whether that equivalent is soul, nature or the notion of actuality more generally - whatever that metaphysical item is which is the immaterial cause to the matter of its having the kind of activity it has: the force, so to speak, existing in the matter, as soul is the cause to a body of its being actually a living body. We may not think of 'being a living body' as a kind of activity, but for Aristotle, being alive or being anything else is to exist in actuality ( $\dot{v} v \varepsilon \rho \varepsilon^{\prime} \alpha$ ) , which is for him a kind of activity without movement. The Stoic view is remarkably close to this except, because they believe only bodies can be causes, they deny there are activities without movement. They do, however, maintain a distinction between the cause and the matter and, as does Aristotle, they believe the cause acts to confer cohesion to the matter. Galen gives the most complete summary of their view in his work on Cohesive Causes:

The first philosophers of my acquaintance to speak of a cohesive cause were the Stoics. Their view is that from the four elements are produced those bodies that Aristotle calls homoiomerous and that are described by Plato as 'the first to be generated,' while all other bodies are simply compounds of these. Of the elements themselves, some they call material and some active and dynamic. They maintain that the material elements are held together by those that are dynamic, fire and air being dynamic and active in their view, while earth and water are material. They say that, when the elements are intermingled, the dynamic wholly penetrate the material, that is to say, air and fire penetrate water and earth. Air is cold

50 See especially Frede (1987), Hankinson (1998), Bobzien (1999), and papers in Coughlin, Leith and Lewis (2020).

$5^{1} \quad$ See $n .14$ above. 
and fire is hot. The natural effect of air is to consolidate and thicken a substance, whereas fire naturally causes expansion, loosening and widening. The two active elements have fine parts and the other two thick parts. Every substance with fine parts the Stoics call spirit (sc. pneuma), and they think that the function of this spirit is to produce cohesion in natural and in animal bodies. By natural bodies I mean those that are produced by nature and not by human skill, like stones, gold, wood and those parts of the animal body that are called the primary and homoiomerous parts, that is, nerves, arteries, veins, cartilages, bones and everything else of the same sort. Men join bits of wood together with glue, nails, pegs, clay, gypsum and lime. Similarly nature is found connecting all the parts of the body so as to form a united whole by means of cartilage, ligaments and tendons. If you like, you can call the parts of the body that produce this union in the simple members cohesive causes of the compounds, and the same term can be applied to clay, gypsum, lime and the other things that serve the same purpose in externals which are connected by the skill of man and not by nature. It is not these, however, but rather material substance with fine parts that the Stoics call a cohesive cause.

GAL. CC 1.1-5, 53,2-55,3 Lyons, trans. LYONS ${ }^{52}$

Galen's summary, that pneuma (a mixture of fire and air) is the active element and brings about cohesion in the material elements, earth and water, by producing a two-fold movement outward and inward, is echoed in numerous other ancient sources..$^{53}$ Sextus Empiricus tells us that the Stoics also called 'what holds together ( $\tau \dot{o}$ ovvéxov) the whole compound' the soul. ${ }^{54}$ Galen's other claim that things, like glue and nails, ligaments and tendons, can be called synechon, echoes the earlier use of the term, where it meant a binding part, as opposed to an active cause. ${ }^{55}$ Galen himself rejects the Stoic cohesive

$5^{2}$ cf. Galen, De plenitudine liber 3 (VII.525 K.) '... most of those who propose the cohesive ca-

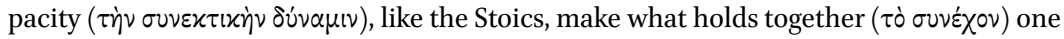
thing and what is held together ( $\tau \dot{\delta} \sigma v v \varepsilon \chi o ́ \mu \varepsilon v o v)$ another. For the pneumatic substance

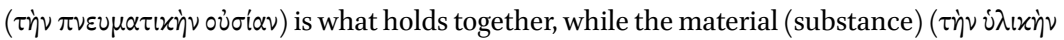

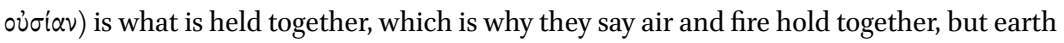
and water are held together.'

53 [Gal.] Def. 96, XIX.372.1-2 K.; Plutarch, De Stoicorum repugnantiis 43, 1053f3-7.

54 Sextus Empiricus, Adversus Mathematicos 7.234.2-4 '[Some Stoics] assert soul is said in

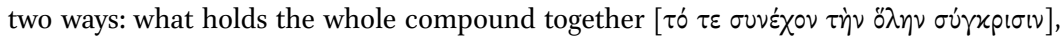

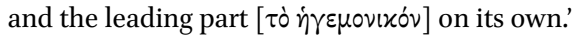

55 It is used in a similar way in Plutarch, Quaestiones Convivales $8.10,735 \mathrm{e} 5-\mathrm{f} 2$, where the loss of leaves in autumn is explained in terms of the mixture ( $x p \hat{\alpha} \sigma \varsigma \varsigma)$ no longer being able to

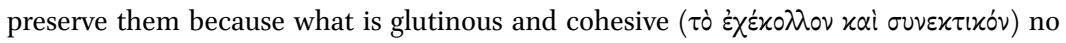
longer remains in it. 
cause altogether in his work On Cohesive Causes, arguing that either (a) every whole needs a cohesive cause, in which case pneuma will also need a cohesive cause and we get a regress; or (b) some things need cohesive causes, while others are self-cohesive, in which case Galen thinks a much better case could be made for something like adamantine to be self-cohesive than hot air, since things like adamantine are solid and less prone to disperse (Gal. CC 6.2-5, 61,26-63,16 Lyons).

One of the most remarkable differences between the Aristotelian and Stoic notion of the cohesive cause, however, is what it says about us, or at any rate about how we fall apart. Atlas may be strong and eternal, but our cohesion is limited. Aristotle blames the instrument. The Stoics also blame the soul - at least, the Stoic-influenced Pneumatist physician, ${ }^{56}$ Athenaeus of Attalia sees the source of incoherence in the powers of the soul itself:

Old age requires a more exact regimen and additional aids. For the psy-

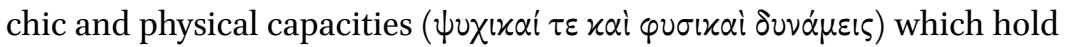

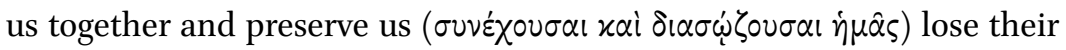
strength, their functions are brought to an end and the body wrinkles and becomes malnourished, loose and dry. And so when the capacity

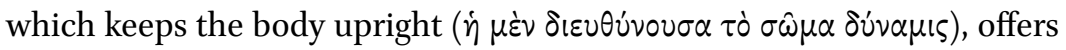
resistance against external things that cause us injury, and resists in ac-

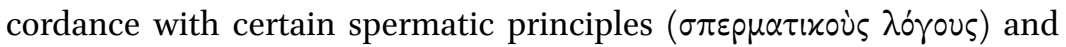
natural necessities ( $\varphi v \sigma i x \dot{\alpha} \varsigma \dot{\alpha} v \dot{\alpha} \gamma \varkappa \alpha \varsigma$ ), falls to the floor (i்ò $\pi \dot{\delta} \delta \alpha \varsigma \chi \omega p \hat{\text {, }}$ i.e. declines in strength), the body is easily affected and easily injured, requiring but a small cause and chance influence for harm. At the start, then, from an early age, one should also take precautions for the time of old age. For as those who wear out their cloak in the summer spend the winter in tatters, so those who in their youth neglect their bodily strength suffer the clothes of old age with great difficulty.

athenaeus of attalia, quoted in Oribasius, Collectiones Medicae (libri incerti 39) $140,13-36$ Raeder

I think we must enjoy our summers.

56 On the role of pneuma in the Pneumatist school of medicine, see Coughlin and Lewis (2020). On Athenaeus' relationship to thinkers other than the Stoics, see Coughlin (2018) $109-13$. 


\section{Acknowledgments}

The research and writing of this paper were funded by a postdoctoral fellowship from the Deutsche Forschungsgemeinschaft (German Research Foundation) - Exzellenzcluster 264 Topoi. Die Formation und Transformation von Raum und Wissen in den antiken Kulturen - Projekt-ID 39235742 held at Humboldt-Universität zu Berlin. Additional funding saw it to completion: fellowships at Einstein Centre Chronoi in Berlin and from the Deutsche Forschungsgemeinschaft (German Research Foundation) - SFB 980 Episteme in Bewegung. Wissenstransfer von der Alten Welt bis in die Frühe Neuzeit Projekt-ID 191249397. The first draft was presented at the conference, Ancient Holisms, held in London 11-12 September 2017; the last, at Philip van der Eijk's Ancient Medicine Research Colloquium at the Institut für Klassische Philologie, Humboldt-Universität zu Berlin, on 18 May 2020. I am grateful to audiences at both, with special thanks to Elizabeth Craik, Philip van der Eijk, P. N. Singer, and Chiara Thumiger for helpful comments. Many thanks also to Gábor Betegh, David Ebrey, and three anonymous reviewers for comments on the written draft.

\section{Bibliography}

Ackrill, J. L. 'Aristotle's Definitions of Psuche.' Proceedings of the Aristotelian Society, 73 (1972) 119-33.

Ainsworth, T. 'Form vs. Matter' In The Stanford Encyclopedia of Philosophy, ed. E. N. Zalta. Metaphysics Research Lab, Stanford University (2016). Available at https:// plato.stanford.edu/ archives/spr2o16/entries/form-matter/.

Bobzien, S. 'Chrysippus' Theory of Causes.' In Topics in Stoic Philosophy, ed. K. Ierodiakonou. Oxford: Oxford University Press (1999).

Choulant, J. L. Handbuch der Bücherkunde für die ältere Medicin, zur Kenntniss der griechischen, lateinischen und arabischen Schriften im ärztlichen Fache und zur bibliographischen Unterscheidung ihrer verschiedenen Ausgaben, Uebersetzungen und Erläuterungen. Leipzig: L. Voss (1841).

Choulant, J. L., F. H. Garrison, E. C. Streeter, and M. Frank. History and Bibliography of Anatomic Illustration in Its Relation to Anatomic Science and the Graphic Arts. Chicago: University of Chicago Press (1920).

Cohen, S. M. Aristotle on Nature and Incomplete Substance. Cambridge and New York: Cambridge University Press (1996).

Cohen, S. M. 'Aristotle's Metaphysics.' In The Stanford Encyclopedia of Philosophy, ed. E. N. Zalta. Metaphysics Research Lab, Stanford University (2016). https://plato .stanford.edu/archives/win2o16/entries/aristotle-metaphysics/. 
Coughlin, S. 'Athenaeus of Attalia on the Psychological Causes of Bodily Health.' In Mental Illness in Ancient Medicine: From Celsus to Paul of Aegina, ed. C. Thumiger and P. N. Singer. Leiden: Brill (2018) 109-42.

Coughlin, S., and O. Lewis. 'Pneuma and the Pneumatist School of Medicine.' In The Concept of Pneuma after Aristotle, ed. S. Coughlin, D. Leith and O. Lewis. Berlin: Edition Topoi (2020) 203-36.

Coughlin, S., D. Leith and O. Lewis. The Concept of Pneuma after Aristotle. Berlin Studies in the Ancient World. Berlin: Edition Topoi (2020).

Cross, R. Duns Scotus. Oxford: Oxford University Press (1999).

D’Acquisto, F., G. Piras and L. Rattazzi. 'Pro-Inflammatory and Pathogenic Properties of Annexin-A1: The Whole Is Greater than the Sum of Its Parts.' Biochemical Pharmacology, 85.9 (May 1, 2013): 1213-18.

Elliott, G. Global Business Information Technology: An Integrated Systems Approach. Harlow and New York: Pearson Addison Wesley (2004).

Falcon, A. Aristotle and the Science of Nature: Unity Without Uniformity. Cambridge: Cambridge University Press (2005).

Fine, K. 'Things and Their Parts.' Midwest Studies in Philosophy, 23.1 (1999) 61-74.

Fine, K. 'Towards a Theory of Part.' Journal of Philosophy, 107.11 (2010) 559-89.

Forrest, J. Y.-L. General Systems Theory: Foundation, Intuition and Applications in Business Decision Making. Cham: Springer (2018).

Frede, M. Essays in Ancient Philosophy. Minneapolis: University of Minnesota Press (1987).

Frede, M. 'The Original Notion of Cause.' In Essays in Ancient Philosophy, ed. M. Frede. Minneapolis: University of Minnesota Press (1987) 125-5o. Originally printed in Doubt and Dogmatism: Studies in Hellenistic Epistemology, ed. J. Barnes, M. F. Burnyeat and M. Schofield. Oxford: Oxford University Press (1980) 217-49.

Fuller, A. R. Insight into Value: An Exploration of the Premises of a Phenomenological Psychology. Albany: SUNY Press (1990).

Graham, D. W. 'Plato and Anaximenes.' Études Platoniciennes [Online], 12 (2015). http:// journals.openedition.org/etudesplatoniciennes/706.

Hankinson, R. J. 'Evidence, Externality and Antecedence: Inquiries into Later Greek Causal Concepts.' Phronesis, 32.1 (1987) 80-10o.

Hankinson, R. J. Cause and Explanation in Ancient Greek Thought. Oxford: Oxford University Press (1998).

Hanson, B. What Holism Can Do for Social Theory. Routledge Studies in Social and Political Thought. New York: Routledge (2014).

Hanson, B. General Systems Theory. Beginning with Wholes. London and New York: Routledge (2013).

Harte, V. Plato on Parts and Wholes: The Metaphysics of Structure. Oxford: Oxford University Press (2002). 
Havrda, M. The So-Called Eighth Stromateus by Clement of Alexandria: Early Christian Reception of Greek Scientific Methodology. Leiden: Brill (2016).

Heider, G. M. 'More about Hull and Koffka.' American Psychologist, 32.5 (1977) 383.

Johnston, Mark. 'Hylomorphism.' Journal of Philosophy, 103.12 (2006) 652-98.

Kirk, G. S., J. E. Raven and M. Schofield. The Presocratic Philosophers: A Critical History with a Selection of Texts. Cambridge: Cambridge University Press (1999).

Koslicki, K. Form, Matter, Substance. Oxford and New York: Oxford University Press (2018).

Koslicki, K. 'Towards a Hylomorphic Solution to the Grounding Problem.' Royal Institute of Philosophy Supplements, 82 (July 2018) 333-64.

Koslicki, K. 'Towards a Neo-Aristotelian Mereology.' Dialectica, 61.1 (March 2007) 127-59.

Lasson, A. Aristoteles Metaphysik. Jena: E. Diederichs (1907).

Long, A. A., and D. N. Sedley. The Hellenistic Philosophers: Volume 1, Translations of the Principal Sources with Philosophical Commentary. Cambridge: Cambridge University Press (1987).

Marks, F., U. Klingmüller and K. Müller-Decker. Cellular Signal Processing: An Introduction to the Molecular Mechanisms of Signal Transduction. Heidelberg: Garland Science (2008).

Marmodoro, A. 'Aristotle's Hylomorphism Without Reconditioning.' Philosophical Inquiry, 37.1-2 (2013) 5-22.

Menn, S. 'On Socrates' First Objections to the Physicists (Phaedo 95 E 8-97 B 7).' Oxford Studies in Ancient Philosophy, 38 (2010) 37-68.

Menn, S. 'Aristotle's Definition of Soul and the Programme of the De Anima.' Oxford Studies in Ancient Philosophy 22 (2002) 83-139.

Menn, S. 'Metaphysics Z10-16 and the Argument-Structure of Metaphysics Z.' Oxford Studies in Ancient Philosophy, 21 (2001) 83-134.

Menn, S. Plato on God as Nous. Carbondale: Southern Illinois University (1995).

Mirrione, C. Theory and Terminology of Mixture in Galen: the Concepts of krasis and mixis in Galen's Thought. Dissertation Humboldt-Universität zu Berlin (2017).

Peramatzis, M. 'Aristotle's Hylomorphism:The Causal-Explanatory Model.' Metaphysics, 1.1 (May 21, 2018) 12-32.

Scalambrino, F. Philosophical Principles of the History and Systems of Psychology: Essential Distinctions. Cham: Palgrave Macmillan (2018).

Scaltsas, T. Substances and Universals in Aristotle's Metaphysics. Ithaca: Cornell University Press (1994).

Schuster, P. 'A Beginning of the End of the Holism versus Reductionism Debate?: Molecular Biology Goes Cellular and Organismic.' Complexity, 13.1 (September 2007) 10-13.

Sedley, D. 'The Dramatis Personae of Plato's Phaedo.' In Philosophical Dialogues: Plato, Hume, Wittgenstein, ed. T. J. Smiley. Oxford: Oxford University Press (1995) 3-26. 
Shields, C. 'Aristotle's Psychology > A Fundamental Problem about Hylomorphism.' In Stanford Encyclopedia of Philosophy, ed. E. N. Zalta. Metaphysics Research Lab, Stanford University (2016). Available at https://plato.stanford.edu/entries/ aristotle-psychology/suppli.html.

Singer, P. N., P. J. van der Eijk and P. Tassinari. Galen. Works on Human Nature. Volume 1, 'Mixtures (De temperamentis).' Cambridge Galen Translations. Cambridge: Cambridge University Press (2018).

Vallero, D. A. Biomedical Ethics for Engineers: Ethics and Decision Making in Biomedical and Biosystem Engineering. Amsterdam: Elsevier (2011).

Vlastos, G. Studies in Greek Philosophy, Volume I: The Presocratics. Princeton: Princeton University Press (1996).

Ward, T. M.John Duns Scotus on Parts, Wholes, and Hylomorphism. Leiden and Boston: Brill (2014).

Witt, C. 'Hylomorphism in Aristotle.' The Journal of Philosophy, 84.11 (1987) 673-79.

\section{Primary Texts: Editions and Translations Used}

Aëtius, Placita Philosophorum (Aët.): Doxographi Graeci. Ed. H. Diels. Berlin: Reimer (1879) 273-444.

Alcmaeon of Croton: See DK

Alexander of Aphrodisias, In Aristotelis Metaphysica Commentaria (Alex. Aphr. in Arist. Metaph.): Alexandri Aphrodisiensis in Aristotelis Metaphysica commentaria. Ed. M. Hayduck. Commentaria in Aristotelem Graeca 1. Berlin: Reimer (1891).

Anaxagoras (Anax.): See DK

Aristotle, De anima (Arist. De an.): Aristotelis De anima. Ed. W. D. Ross. Oxford Classical Texts. Oxford: Oxford University Press (1956).

Aristotle, De generatione animalium (Arist. Gen. an.): Aristotelis De Generatione Animalium. Ed. H. J. Drossaart Lulofs. Oxford Classical Texts. Oxford: Oxford University Press (1965).

Aristotle, De Generatione et Corruptione (Arist. Gen. corr.): Aristote. De la Génération et de la corruption. Ed. and trans. M. Rashed. Collection des Universités de France. Paris: Les Belles Lettres (2005).

Aristotle, Partibus Animalium (Arist. Part. an.): Aristote. Les parties des animaux. Ed. and trans. P. Louis. Collection des Universités de France. Paris: Les Belles Lettres (1993).

Aristotle, Metaphysica (Arist. Metaph.): Aristotelis Metaphysica. Ed. W. Jaeger. Oxford Classical Texts. Oxford: Oxford University Press (1957).

Aristotle, Meteorologica (Arist. Mete.): Aristotelis Meteorologicorum Libri Quattuor. Ed. F. H. Fobes. Cambridge MA: Harvard University Press (1919). 
Aristotle, Physica (Arist. Phys.): Aristotelis Physica. Ed. W. D. Ross. Oxford Classical Texts. Oxford: Oxford University Press (1950).

Aristotle, Problemata (sp.) ([Arist.] Pr.): Aristotle. Volume XVI. Problems, Books 20-38. Ed. and trans. R. Mayhew. Rhetoric to Alexander. Ed. and trans. D. C. Mirhady. Loeb Classical Library 317. Cambridge MA: Harvard University Press (2011) 1-449.

Clement of Alexandria, Stromateis (Clem. Strom.): Havrda, Matyáš. The So-Called Eighth Stromateus by Clement of Alexandria: Early Christian Reception of Greek Scientific Methodology. Leiden: Brill (2016).

Democritus (Democr.): See DK

Diogenes (Diog.): See DK

DK = Diels Kranz: Die Fragmente der Vorsokratiker. Ed. H. Diels and W. Kranz. Sixth Edition. Berlin: Weidmann (1951-1952).

Empedocles (Emped.): See DK

Euripides, Supplices (Eur. Supp.): Euripidis Fabulae. Ed. J. Diggle. Vol. 2. Oxford: Oxford University Press (1981) 3-53.

Galen, Adversus Iulianum (Gal. Adv. Iul.): Galeni Adversus Lycum et Adversus Iulianum libelli. Ed. E. Wenkebach. Corpus Medicorum Graecorum V 10,3. Berlin: AkademieVerlag (1951) 33-70.

Galen, Claudii Galeni Opera omnia. Ed. C. G. Kühn. 22 Vols. Leipzig: Knobloch (1821-1833).

Galen, De Causis Contentivis (Gal. CC): Galeni De Partibus Artis Medicativae, De Causis Contentivis, De Diaeta in Morbis Acutis Secundum Hippocratem Libelli Versio Arabica, edidit et in linguam Anglicam vertit M. Lyons; De Partibus Artis Medicativae, De Causis Contentivis Libelli Editio ab H. Schöne alterius a K. Kalbfleisch curata, retractaverunt J. Kollesch, D. Nickel, G. Strohmaier. Corpus Medicorum Graecorum Supplementum Orientale II. Berlin: Akademie-Verlag (1969) 52-73, 133-41.

Galen, De Plenitudine (Gal. Plen.): Claudii Galeni opera omnia. Ed. C. G. Kühn. Vol. 7. Leipzig: Knobloch (1824) 513-83.

Galen, De Symptomatum Causis (Gal. Caus. Symp.): Claudii Galeni Opera Omnia. Ed. C. G. Kühn. Vol. 7. Leipzig: Knobloch (1824) 85-272.

Galen, Definitiones Medicae (sp.) ([Gal.] Def.): Claudii Galeni Opera Omnia. Ed. C. G. Kühn. Vol. 19. Leipzig: Knobloch (1830) 346-462.

Galen, Introductio sive Medicus (sp.) ([Gal.] Int.): Galien [sp.]. Tome III. Le Médecin. Introduction [=Int.]. Ed. and trans. C. Petit. Collection des Universités de France. Paris: Les Belles Lettres (2009).

Galen, Synopsis Librorum Suorum de Pulsibus (Gal. Syn. Puls.): Claudii Galeni Opera Omnia. Ed. C. G. Kühn. Vol. 9. Leipzig: Knobloch (1825) 431-533.

Hesiod, Theogonia (Hes. Theog.): Hesiod. Theogony. Ed. M. L. West. Oxford: Clarendon Press (1966).

Hippocrates, De Carnibus (Hp. Carn.): Hippocrates. Volume VIII. Ed. and trans. Paul Potter. Loeb Classical Library 482. Cambridge MA: Harvard University Press (1995) 127-166. 
Hippocrates, De Flatibus (Hp. Flat.): Hippocratis Indices Librorum, Iusiurandum, Lex, De arte, De medico, De Decente Habitu, Praeceptiones, De Prisca Medicina, De Aere Locis Aquis, De Alimento, De Liquidorum Usu, De Flatibus. Edidit J. L. Heiberg, Corpus Medicorum Graecorum I 1. Leipzig and Berlin: Teubner (1927) 91-101.

Hippocrates, Mochlicum (Hp. Mochl.): Hippocrates. Volume III. Ed. and trans. E. T. Withington. Loeb Classical Library 149. Cambridge MA: Harvard University Press (1928) 399-45o.

Hippocrates, OEuvres complètes d'Hippocrate. Ed. and trans. É. Littré. 10 Vols. Paris: J.-B. Ballière (1839-1861).

Hippocrates, Prorrheticus II (Hp. Prorrh. II): Hippocrates. Volume VIII. Ed. and trans. Paul Potter. Loeb Classical Library 482. Cambridge MA: Harvard University Press (1995) 213-94.

Oribasius, Collectiones Medicae (Orib. Coll. Med.): Oribasii Collectionum Medicarum Reliquiae. Vol. IV, libri XLIX-L, Libri incerti, Eclogae medicamentorum. Ed. J. Raeder. Corpus Medicorum Graecorum VI 2,2. Leipzig et Berlin (1933).

Plato, Phaedo (Pl. Phd.): Platonis Opera. Ed. J. Burnet. Vol. 1. Oxford Classical Texts. Oxford: Oxford University Press (1900).

Plato, Theaetetus (Pl. Tht.): Platonis Opera. Ed. J. Burnet. Vol. 2. Oxford Classical Texts. Oxford: Oxford University Press (1900).

Plato, Timaeus (Pl. Ti.): Platonis Opera. Ed. J. Burnet. Vol. 4. Oxford Classical Texts. Oxford: Oxford University Press (1900).

Plutarch, De Stoicorum Repugnantiis (Plut. Stoic. repug.): Plutarchi Moralia VI, 2. Ed. R. Westman and M. Pohlenz. 2nd edn. Bibliotheca scriptorum Graecorum et Romanorum Teubneriana (Scriptores Graeci). Leipzig: Teubner (1959) 2-58.

Plutarch, Placita philosophorum (sp.) ([Plut.] Placit.): Plutarchi Moralia V,2,1. Ed. J. Mau. Bibliotheca Scriptorum Graecorum et Romanorum Teubneriana (Scriptores Graeci). Leipzig: Teubner (1971) 50-153.

Sextus Empiricus, Adversus Mathematicos (S. E. M.): Sexti Empirici Opera. Ed. H. Mutschmann. Vol. 2. Bibliotheca Scriptorum Graecorum et Romanorum Teubneriana (Scriptores Graeci). Leipzig: Teubner (1914).

Pyrrhoniae hypotyposes (S. E. PH): Sexti Empirici Opera. Ed. H. Mutschmann. Vol. I. Bibliotheca Scriptorum Graecorum et Romanorum Teubneriana(Scriptores Graeci). Leipzig: Teubner (1912).

Simplicius, In Aristotelis De Caelo Commentarius (Simpl. in Arist. De cael.): Simplicii in Aristotelis De caelo commentaria. Ed. I. L. Heiberg. Commentaria in Aristotelem Graeca 7. Berlin: Reimer (1894).

Simplicius, In Aristotelis Physicorum Libros Commentaria (Simpl. in Arist. Phys.): Simplicii in Aristotelis Physicorum libros quattuor priores commentaria. Ed. H. Diels. Commentaria in Aristotelem Graeca 9. Berlin: Reimer (1882).

Xenophon, Memorabilia (Xen. Mem.): Xenophon. Volume IV. Memorabilia, Oeconomicus. Trans. E. C. Marchant. Symposium, Apology. Trans. O. J. Todd. Loeb Classical Library 168. Cambridge MA: Harvard University Press (1923). 